Research Paper: Proposal

\title{
Transformation of the Mediation Role of Judges in Corruption Crimes in a Perspective of Legal Benefits
}

\author{
Achmad Yani ${ }^{1}$, Ismail Yusuf Panessai ${ }^{2}$ \\ ${ }^{1}$ Faculty of Social Science, Universiti Sains Malaysia. Penang, Malaysia. \\ ${ }^{2}$ Universiti Pendidikan Sultan Idris. Tanjong Malim, Perak. Malaysia.
}

Article History

Received:

13.07.2021

Revised:

26.08.2021

Accepted:

01.09 .2021

*Corresponding Author:

Achmad Yani

Email:

achmad.yani@student.usm.my

This is an open access article, licensed under: $\mathrm{CC}-\mathrm{BY}-\mathrm{SA}$

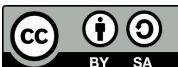

Abstract: The transformation of the role of judges in criminal cases needs to be considered to prioritize the return of state financial losses in the perspective of the usefulness of the law. This study uses a descriptive study with qualitative data analysis. This study answers the questions of how is the implementation of the role of judges in criminal cases in Indonesia; and what is the role of judges in criminal cases in the perspective of justice, usefulness and legal certainty. The creation of laws that serve the interests of the State cannot be separated from the role of judges. Therefore, the role of judges is important to transform that the core in the creation of laws is the harmonious implementation of values and principles which are then manifested in the behavior of the "pattern setting group" which can be interpreted as a group of experts. The power of law in the narrow sense is the judge.

Keywords: Corruption, Benefit of the Law, Judge Mediation. 